\title{
The Evolution of School Failure Risk During the 2000 Decade in Spain: Analysis of PISA Results with a Two-Level Logistic Model
}

Evolución del riesgo de fracaso escolar en España durante la década del 2000: Análisis de los resultados de PISA con un modelo logístico de dos niveles

JuAN MANUEL GUIO JAIMES

Universidad de Barcelona jguiojai7@alumnes.ub.edu
ÁLVARO CHOI DE MENDIZÁBAL

Universidad de Barcelona alvarochoi@ub.edu
Abstract: School failure has been one of the principal problems of the Spanish educational system during recent decades. This paper offers a perspective of the evolution of the factors that have had a significant influence over the risk of school failure considering personal, household and school characteristics through multilevel logistic regression analyses of PISA 2000, 2003, 2006 and 2009 microdata.

Keywords: school failure; multilevel logistic regression; PISA; compulsory education.
Resumen: El fracaso escolar ha sido uno de los principales problemas del sistema educativo español durante las últimas décadas. Este trabajo ofrece una perspectiva de la evolución en los factores que tienen una influencia significativa sobre el riesgo de fracaso escolar considerando características personales, familiares y de las escuelas por medio de un análisis de regresión con un modelo logístico multinivel para los micro datos de PISA 2000, 2003, 2006 y 2009.

Palabras clave: fracaso escolar; regresión logística multinivel; PISA; educación secundaria obligatoria. 


\section{INTRODUCTION}

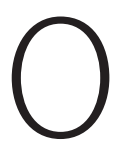

vercoming high rates of school failure is one of the most complex challenges faced by Spanish society. National and international studies, such as Fernández Enguita et al. (2010), and OECD reports (2010, 2011), address the problem of the low performance of Spanish students compared to their European peers. Results are clear: Spain faces higher levels of school failure and early school dropout.

The broad definition of school failure includes all forms of not achieving the educational objectives determined by society as the minimum necessary to be integrated into the labor market and to become a productive member of the community. Accordingly, the definition of school failure chosen in this paper includes all the individuals who are not able to complete compulsory secondary education (ESO) at the age of 16.

School failure in Spain appears to have structural characteristics, as it has been present in the educational system for more than 30 years, with figures fluctuating around 30\% during the last two decades. Failure to accomplish the objective proposed by the Lisbon Strategy in 2010 and difficulties in achieving the Europe 2020 strategy of reducing the early school leaver rate in EU countries to less than $10 \%$ are indicators of issues in addressing the causes of the problem.

The aim of this paper is to analyze the evolution of the factors that determined school failure risk during the 2000 decade in Spain. In this paper, following the work of authors such as Schleicher (2007), school failure risk is defined as the probability of obtaining a score below level-2 in reading competency in the Programme for International Student Assessment (PISA). The selection of reading competency as the main area in this analysis is due to the emphasis that this competency has in two of the four PISA tests (2000 and 2009).

The analysis is performed using 2000, 2003, 2006 and 2009 PISA micro-data for Spain. This should allow the observation of variations in the determinants over time, and their importance as predictors of school failure risk, broadening the scope of previous works such as Calero et al. (2010) or Choi and Calero (in press) and permitting the introduction of methodological improvements.

Table 1 compares real school failure rates in Spain and the risk of school failure in all the PISA test competencies. The measure of school failure risk in PISA tends to underestimate the real volume of students who fail. 
Table 1: Risk of school failure by competencies in the Spain PISA tests

\begin{tabular}{lcccc} 
& 2000 & 2003 & 2006 & 2009 \\
\hline School failure (real) & 26,6 & 28,7 & 30,8 & 25,9 \\
\hline Reading competence & 16,7 & 18,5 & 19,1 & 20,0 \\
\hline Mathematics competence & 25,0 & 20,4 & 17,2 & 21,8 \\
\hline Scientific Knowledge competence & 20,6 & 20,3 & 14,0 & 17,7 \\
\hline
\end{tabular}

Source: OECD-PISA, 2000, 2003, 2006 and 2009 databases and Ministerio de Educación, Cultura y Deporte (2011).

This paper is structured as follows: Section 2 explains and justifies the individual, household and school-level variables considered in the analysis. Section 3 presents the data and the methodology, while Section 4 discusses the results. Finally the main conclusions are presented in the last section.

\section{DETERMINANTS OF ACADEMIC PERFORMANCE AND SCHOOL FAILURE}

The present section has been divided into three sub-sections according to the three blocks of explicative variables considered in this paper: personal, family and school characteristics.

\section{Personal characteristics}

The differences in the academic performance of students depend on a number of characteristics that are distinctive at an individual level, and have a direct influence on the probability of school success. Gender appears to be an important personal determinant that affects the academic performance of students. For example, there is a significant difference in the ESO graduation rates between males and females. Using year 2006-2007 data, Fernández Enguita (2010) found a variation of almost 14 percentage points for females over males in graduation rates. A capacity for organization, discipline and attention appears to be a more common characteristic of female students, who also seem to have an advantage in the learning processes. It is therefore to be expected that a positive relation will be found between obtaining a high score in the PISA reading test and being female. It is also anticipated, that a lower proportion of female students will be at risk of school failure compared with 
their male peers. It is important to mention that this result does not hold for the PISA math test (Calero et al., 2010). Carrington et al. (2008) attempted to analyze whether the gender gap in performance could be explained by teacher gender, in a study of 11-year-old British students. However they found no evidence of differences in the attitudes or approaches of teachers related to the gender of their students.

Another characteristic linked to the degree of maturity of the pupils is the month of birth of the student. Crawford et al. (2011) found evidence that students born between January and March seem to obtain consistently better grades than students who were born from October to December. Similarly, García Montalvo (2011) in a recent study in Spain, using the TIMSS and PIRLS databases, found evidence of a positive relationship between being born in the first and second quarters of the year and educational achievement measured by the scores of the students in the PISA international standardized tests. Data provided by the Instituto Vasco de Investigación y Evaluación Educativa (Basque Institute for Educational Research and Assessment) (2009) point in the same direction as the academic results of $4^{\circ}$ grade primary school and $2^{\circ}$ grade ESO students are influenced by the quarter of the year in which the student was born, although these differences seem to dissipate as the students get older. Consequently, a variable that accounts for the month of birth has been introduced to test for differences in the possible outcomes of students in the PISA tests.

Finally, students who are significantly older than their own school cohort seem to have some disadvantages in motivation, engagement and performance compared to their peers in the appropriate grade for their age (Martin, 2009). There are significant examples in the literature that provide evidence of a negative relation between grade retention and educational outcomes (Holmes, 1989; Jimmerson, 2001). However this variable has been intentionally excluded from our estimations due to endogeneity issues between academic achievement and grade repetition ${ }^{1}$. Table 2 shows the proportion of students who obtain a low result in the PISA reading competency in the four PISA evaluations.

1 In preliminary estimations of the results presented in Section 4 the variable "grade retention" was included, the results suggesting a strong link between grade retention and academic performance. However, we chose not to incorporate the variable in the final estimations in order to avoid bias generated by the introduction of an endogenous variable. 
Table 2: Probabilities of obtaining a grade under level-2 in the PISA reading test according to personal characteristics

\begin{tabular}{|c|c|c|c|c|}
\hline PERSONAL VARIABLES & 2000 & 2003 & 2006 & 2009 \\
\hline \multicolumn{5}{|l|}{$\overline{\text { GRADE }}$} \\
\hline $2^{\circ} \mathrm{ESO}$ & $74,19 \%$ & $68,06 \%$ & $69,35 \%$ & $66,96 \%$ \\
\hline $3^{\circ} \mathrm{ESO}$ & $42,05 \%$ & $39,32 \%$ & $38,37 \%$ & $35,78 \%$ \\
\hline $4^{\circ} \mathrm{ESO}$ & $5,46 \%$ & $9,68 \%$ & $7,90 \%$ & $7,38 \%$ \\
\hline \multicolumn{5}{|l|}{ GENDER } \\
\hline Male & $20,81 \%$ & $24,90 \%$ & $25,14 \%$ & $24,19 \%$ \\
\hline Female & 10,94 & $11,83 \%$ & $13,00 \%$ & $13,89 \%$ \\
\hline \multicolumn{5}{|l|}{ BIRTH MONTH } \\
\hline January to March & $14,68 \%$ & $17,59 \%$ & $16,47 \%$ & $16,87 \%$ \\
\hline October to December & $19,13 \%$ & $21,17 \%$ & $22,01 \%$ & $20,43 \%$ \\
\hline \multicolumn{5}{|l|}{ COUNTRY OF BIRTH } \\
\hline Spain & $15,34 \%$ & $17,39 \%$ & $17,81 \%$ & $16,98 \%$ \\
\hline Others & $29,95 \%$ & $34,34 \%$ & $36,82 \%$ & $35,65 \%$ \\
\hline \multicolumn{5}{|l|}{ ORIGIN OF THE STUDENT } \\
\hline National students & $16,31 \%$ & $17,85 \%$ & $18,22 \%$ & $18,43 \%$ \\
\hline First generation immigrants & $33,33 \%$ & $40,27 \%$ & $40,86 \%$ & $38,23 \%$ \\
\hline Second generation immigrants & & $29,54 \%$ & $32,99 \%$ & $35,45 \%$ \\
\hline AGGREGATE MEAN & $17,37 \%$ & $19,95 \%$ & $20,44 \%$ & $19,98 \%$ \\
\hline
\end{tabular}

Source: Own compilation with OECD-PISA, 2000, 2003, 2006 and 2009 databases.

Not all the students in the sample were born in Spain. An increasing number of students among the four PISA waves used in this article have diverse nationalities and origins. Being an immigrant is an important characteristic that seems to increase the risk of school failure (Table 2) and is related with adaptation issues, such as language and cultural differences (McCarthy, 1998). A dummy variable that distinguishes those students born in Spain from those born outside the country is introduced in the 2000 and 2003 waves. In the 2006 and 2009 waves, two dummy variables are introduced to measure the effect of being either a first or second-generation immigrant on the risk of school failure, compared to native students. The language spoken at home appears to be an important determinant of the process of adaptation of immigrants to their new country (Entorf and Minoiu, 2005). 


\section{Household characteristics}

Household attributes and material resources are two important aspects to be considered in the analysis of academic performance. The Coleman Report (1966) provided evidence that family background is the main factor in student academic performance.

Hanushek (1997) showed that differences in household environments, such as students living in single-parent families or coming from lower socio-economical backgrounds, are relevant for individual academic achievement. Haveman and Wolfe (1995) state that it is a household's background characteristics that have the most powerful effect on the academic achievement of students.

There is an important difference in the academic performance of students whose parents belong to a managerial or professional category compared to those from families where the parents are manual workers (Cohen, 1987). The former are a small segment of the population and have significant advantages in school achievement, grades and completion rates compared to the latter. Consequently the model presented in Section 3 includes a variable that describes the household member in the highest socio-economic category.

There is ample literature that shows the relationship between the educational level of the parents and the performance of students. Ferguson et al. (1996) posited that parental education accounted for about 24 percent of the variance in student's test scores; Reynolds and Temple (1998) affirm that the level of education of the parents is positively associated with test scores and negatively with grade retention. Consequently it is to be expected that an inverse relation will be observed between the level of education attained by parents and the probability of students being at risk of school failure.

Table 3 illustrates the percentage of students at risk of school failure according to the evaluation results in the PISA reading competency and considering family attributes.

Table 3: Probability of obtaining a grade under level-2 in the PISA reading test considering household characteristics

\begin{tabular}{lcccc} 
SCHOOL VARIABLES & 2000 & 2003 & 2006 & 2009 \\
\hline OCCUPATION OF THE PARENTS & & & & \\
\hline Working & $15,59 \%$ & $16,77 \%$ & $15,86 \%$ & $15,32 \%$ \\
Not working & $19,12 \%$ & $22,03 \%$ & $24,15 \%$ & $22,37 \%$
\end{tabular}




\begin{tabular}{|c|c|c|c|c|}
\hline SCHOOL VARIABLES & 2000 & 2003 & 2006 & 2009 \\
\hline \multicolumn{5}{|l|}{ Socio-economical category } \\
\hline Skilled white-collar worker & $2,91 \%$ & $6,54 \%$ & $8,36 \%$ & $6,37 \%$ \\
\hline Unskilled white-collar worker & $8,03 \%$ & $11,15 \%$ & $11,87 \%$ & $9,56 \%$ \\
\hline Blue-collar worker & $19,11 \%$ & $20,78 \%$ & $22,31 \%$ & $22,05 \%$ \\
\hline \multicolumn{5}{|l|}{ PARENTAL EDUCATION LEVEL } \\
\hline Tertiary education & $8,59 \%$ & $10,51 \%$ & $12,43 \%$ & $10,84 \%$ \\
\hline Compulsory secondary education (ESO) & $11,17 \%$ & $16,87 \%$ & $16,74 \%$ & $18,43 \%$ \\
\hline Primary education & $24,91 \%$ & $25,42 \%$ & $34,89 \%$ & $30,47 \%$ \\
\hline Did not finish primary education & $45,26 \%$ & $40,95 \%$ & $46,33 \%$ & $55,51 \%$ \\
\hline \multicolumn{5}{|l|}{ HOME EDUCATIONAL RESOURCES } \\
\hline Computer, calculator, books and dictionary & $12,23 \%$ & $14,80 \%$ & $14,06 \%$ & $13,56 \%$ \\
\hline Does not have these resources & $22,53 \%$ & $27,01 \%$ & $23,63 \%$ & $22,04 \%$ \\
\hline \multicolumn{5}{|l|}{ HOUSEHOLD CULTURAL POSSESSIONS } \\
\hline Literature, poetry and works of art & $10,71 \%$ & $12,37 \%$ & $13,88 \%$ & $13,37 \%$ \\
\hline Does not have these possessions & $27,37 \%$ & $26,50 \%$ & $29,05 \%$ & $29,55 \%$ \\
\hline AGGREGATE MEAN & $17,37 \%$ & $19,95 \%$ & $20,44 \%$ & $19,98 \%$ \\
\hline
\end{tabular}

Source: Own compilation with OECD-PISA, 2000, 2003, 2006 and 2009 databases.

The possession of cultural resources is expected to have a negative relation to the risk of school failure (Berger et al., 2005). Similarly the possession of a large number of books is correlated with early reading competence in individuals (Aikens and Barbarin, 2008). Two variables that account for the household's cultural environment and the specific material possessions within the household are incorporated in the model, and it is predicted that they will reduce the probability of obtaining a score below level-2 in the PISA reading test.

\section{School characteristics}

School-level determinants refer to the characteristics of the schools, the type of students who enroll in them and their material resources and their allocation. The most relevant factors affecting the risk of school failure seem to be to a significant extent already set before the students enter school, but it is important to determine if the school magnifies or reduces the differences between students with diverse characteristics and risk factors. 
One significant determinant associated with the characteristics of educational institutions is school ownership. State schools contain a larger proportion of immigrant students and they have students with a wider range of characteristics and family backgrounds. The graduation rate from ESO in private schools is almost 20 percent above the rate in public institutions (Ministerio de Educación, 2009).

Interaction between students sharing certain characteristics contributes to the enhancement or the reduction of the academic performance of peers (Coleman et al., 1966). Accordingly the following determinants are introduced: the proportion of females in the school population, the socio-economic characteristics of the students and also the educational level attained by parents.

Another important characteristic related to the interaction between students is their origin. We have therefore introduced a variable that measures the proportion of immigrants in the schools. Two different thresholds are used: $20 \%$ for the years 2000 and 2003, and 30\% for the years 2006 and 2009. The use of two different thresholds is justified by the progressive increase in the percentage of immigrant students who entered the Spanish educational system during the 2000 decade.

Calero and Escardíbul (2007), using PISA-2003, found that there is no significant difference in the performance of the students at different types of schools in Spain, and Cordero et al. (2011) reach the same conclusion, demonstrating that this variable was not relevant in the academic achievement of the students tested in PISA-2009. Considering this empirical evidence, it is to be expected that differences in the ownership of the school are not relevant determinants of school failure risk if socio-economical characteristics are controlled for.

The controversial debate over the importance of a reduced teacher-student ratio in the classroom is also considered in the analysis. While authors such as Krueger (2002) argued for the need to reduce class size in order to improve the quality of education, Hanushek (2003) and Chingos (2010) consider student-teacher ratio to be a factor that does not enhance the quality of education or academic results. To test this, we include a variable that represents student-teacher ratio.

Even though the real effect of school material resources on the academic performance of students is a matter of debate due to the results of international (Hanushek, 2003) and national studies (Calero, Choi and Waisgrais, 2010), variables such as school size and the students-per-computer ratio have been included with the purpose of observing their evolution throughout the 2000 decade. However, as Lavy (2012) warns, resource analysis may not be adequate if endogeneity is not addressed, that is if the fact that schools with certain profiles have higher studentteacher ratios than others is not taken into consideration. This is clearly a research area to be explored in Spain in the future. 
Finally, another group of variables included in the analysis covers the participation of schools in school budget allocation and course content. According to the results observed by Calero and Waisgrais (2009), the effect of these variables is not particularly significant. However, using data from different years, it is still possible to observe interesting results regarding the effect of the autonomy of schools on school failure risk.

Table 4 shows the rate of students who could not achieve results equal to or above level-2 in the PISA reading competency, according to school attributes.

Table 4: Probability of obtaining a grade under level- 2 in the PISA reading test considering school characteristics

\begin{tabular}{|c|c|c|c|c|}
\hline SCHOOL VARIABLES & 2000 & 2003 & 2006 & 2009 \\
\hline \multicolumn{5}{|c|}{ SIZE OF THE COMMUNITY WHERE SCHOOLS ARE LOCATED } \\
\hline Community +100.000 inhabitants & $12,63 \%$ & $17,18 \%$ & $15,29 \%$ & $13,55 \%$ \\
\hline Community +1.000 .000 inhabitants & $10,64 \%$ & $18,02 \%$ & $17,45 \%$ & $18,14 \%$ \\
\hline \multicolumn{5}{|l|}{ TYPE OF SCHOOL } \\
\hline Private government independent & $4,68 \%$ & $11,13 \%$ & $10,14 \%$ & $8,13 \%$ \\
\hline Private government dependent & $10,32 \%$ & $13,02 \%$ & $13,69 \%$ & $11,69 \%$ \\
\hline Public & $21,06 \%$ & $22,93 \%$ & $23,74 \%$ & $23,97 \%$ \\
\hline \multicolumn{5}{|l|}{ SCHOOL SIZE (NUMBER OF STUDENTS) } \\
\hline Over the average & $13,93 \%$ & $12,44 \%$ & $14,29 \%$ & $17,00 \%$ \\
\hline Under the average & $19,63 \%$ & $20,29 \%$ & $22,22 \%$ & $20,66 \%$ \\
\hline \multicolumn{5}{|l|}{ PERCENTAGE OF GIRLS } \\
\hline Over the average & $17,23 \%$ & $17,27 \%$ & $18,39 \%$ & $18,61 \%$ \\
\hline Under the average & $14,39 \%$ & $17,57 \%$ & $19,86 \%$ & $19,78 \%$ \\
\hline \multicolumn{5}{|l|}{ RATIO STUDENTS-COMPUTERS } \\
\hline Over the average & $17,88 \%$ & $22,34 \%$ & $22,60 \%$ & $21,28 \%$ \\
\hline Under the average & $14,76 \%$ & $14,68 \%$ & $16,91 \%$ & $17,33 \%$ \\
\hline \multicolumn{5}{|l|}{ RATIO STUDENTS-TEACHER } \\
\hline Over the average & $8,91 \%$ & $10,65 \%$ & $13,81 \%$ & $12,71 \%$ \\
\hline Under the average & $20,54 \%$ & $22,93 \%$ & $23,25 \%$ & $23,00 \%$ \\
\hline \multicolumn{5}{|l|}{ RATIO IMMIGRANTS-NATIONAL } \\
\hline Immigrant students over $20 \%$ & $33,33 \%$ & $38,14 \%$ & $30,89 \%$ & $26,34 \%$ \\
\hline Immigrant students over $30 \%$ & $28,81 \%$ & $53,42 \%$ & $40,00 \%$ & $30,05 \%$ \\
\hline \multicolumn{5}{|l|}{ EDUCATIONAL SCHOOL ENVIRONMENT } \\
\hline Tertiary education & $7,19 \%$ & $8,93 \%$ & $10,07 \%$ & $10,65 \%$ \\
\hline
\end{tabular}




\begin{tabular}{lllll} 
SCHOOL VARIABLES & 2000 & 2003 & 2006 & 2009 \\
\hline EDUCATIONAL SCHOOL ENVIRONMENT & & & \\
\hline Compulsory secondary education (ESO)14,12\% & $19,23 \%$ & $19,84 \%$ & $22,59 \%$ & \\
Primary education & $26,16 \%$ & $32,07 \%$ & $30,64 \%$ & $58,59 \%$ \\
\hline SOCIO-PROFESSIONAL SCHOOL ENVIRONMENT & & & \\
\hline Skilled white-collar parents & $0,00 \%$ & $0,00 \%$ & $3,50 \%$ & $1,96 \%$ \\
Unskilled white-collar parents & $4,51 \%$ & $6,50 \%$ & $8,86 \%$ & $7,13 \%$ \\
Blue-collar parents & $18,32 \%$ & $20,69 \%$ & $20,79 \%$ & $20,45 \%$ \\
\hline BUDGET MANAGEMENT AUTONOMY & & & & \\
\hline School resposibility & $16,22 \%$ & $11,33 \%$ & $15,18 \%$ & $9,76 \%$ \\
Not a school resposibility & $25,00 \%$ & $21,04 \%$ & $22,63 \%$ & $19,96 \%$ \\
\hline COURSE CONTENT AUTONOMY & & & & \\
\hline School resposibility & $15,89 \%$ & $17,83 \%$ & $19,40 \%$ & $17,57 \%$ \\
Not a school resposibility & $17,72 \%$ & $18,11 \%$ & $18,60 \%$ & $19,35 \%$ \\
\hline AGGREGATE MEAN & $17,37 \%$ & $19,95 \%$ & $20,44 \%$ & $19,98 \%$ \\
\hline
\end{tabular}

Source: Own compilation with OECD-PISA, 2000, 2003, 2006 and 2009 databases.

\section{DATA AND METHODOLOGY}

This section is divided into two parts. The first part describes the data provided by the PISA evaluations, the method employed to gather the data and the strategy necessary to handle this particular kind of database. The second part of the section outlines the econometric technique and model best suited to fit the PISA databases.

\section{Data}

The database for this paper corresponds to the OECD Programme for International Student Assessment (PISA) implemented in the late nineties as a strategy for the periodic international evaluation of the general competence of 15 year-old students. The sample in the present work covers the four PISA evaluations completed during the 2000 decade.

Table 5 describes the size of the sample of students and schools considered for each one of the four PISA evaluations in the present analysis. 
Table 5: Sample size and target population of the Spain PISA tests from 2000 to 2009

\begin{tabular}{lcccc} 
& 2000 & 2003 & 2006 & \multicolumn{1}{c}{2009} \\
\hline Total population of 15 years old & 451,685 & 454,064 & 439,415 & 433,224 \\
\hline Students sample & 6,214 & 10,791 & 19,604 & 25,887 \\
\hline Weighted student participants & 399,055 & 344,372 & 381,686 & 387,054 \\
\hline Schools sample & 185 & 383 & 686 & 889 \\
\hline
\end{tabular}

Source: OECD-PISA, 2000, 2003, 2006 and 2009 databases.

In each PISA evaluation, emphasis is placed on one specific competency. These competencies were reading in the 2000 test, mathematics in 2003, scientific knowledge in 2006 and again reading in 2009.

The PISA test consists of three survey forms, one for the students, one for the parents and one for the head of the school. In Spain the parent questionnaire was omitted and, consequently, the main sources of information were the students and the schools. The student questionnaire is designed to gather information about specific competencies and also background information regarding the personal and household characteristics of the students. The school questionnaire collects information from the schools and makes it possible to match information between students and schools.

The PISA sampling is carried out in two stages. In the first stage, a sample of schools is randomly selected from a list of eligible schools. In the second stage a subsample of 35 students aged 15 years is randomly selected within each school. Student and school level sampling weights are provided to correct marginal deviation from the random probability process of selection. Consequently, sampling weights have been used throughout our analysis to avoid bias in population parameter estimates ${ }^{2}$.

The educational outputs of the PISA evaluation are the scores in the standardized tests that give different values to the abilities of the students. Non-observable random factors that can affect the test result are controlled for through a set of plausible values. This characteristic of the PISA tests implies the need to incorporate the plausible values for each competency in the analysis. Performance in each PISA competency is measured through a set of 5 plausible values. These values cannot be individually interpreted as scores, but as a set they are accurate in

2 OECD (2009a) provides a thorough description of the use of sampling weights with PISA. 
describing the performance of the population, as they contain a random error variance component. Estimations must therefore be performed five times per competency and then averaged. Standard errors are calculated following the same method, and the total variance is determined adding the measurement error and the sampling variances.

Missing values, present in all the PISA evaluations, require a particular approach that allows the true nature of the data to be left unaffected. The methodology that seems most appropriate is the Multiple Imputation strategy (Rubin, 1987), a procedure by which missing data are imputed several times to produce different complete data estimates of the parameters. The estimated parameters are combined to produce an overall estimate of the complete data parameters with minimal effects on the standard error. Multiple imputation by chained equations was performed using the Stata package. This software offers a more flexible method of dealing with missing values, compared to fully-parametric methods like maximum likelihood and Bayesian analysis.

\section{Metbodology}

The analysis of PISA data requires multilevel modeling in order to account for the hierarchical structure of the data and a logit-type specification for the binary response dependent variable. We use a two-level formulation proposed by Raudenbush and Bryk (2002), the first level corresponds to data from the students clustered within schools, and the second level captures the influence of school factors.

Traditional techniques are not suited to accounting for the hierarchical and clustered structure of the data. Multilevel regression takes into account the nested distribution of the data within larger units of concentration, calculating a different equation for each level of aggregation. These models not only identify the relations of different variables within the same level but also the influence of variables from one level to another.

The first level of the multilevel regression corresponds to $i$ students selected in the second stage of the PISA survey and, the second level, to $j$ schools sampled in the previous stage of the survey. The logistic random intercept for a dichotomous dependent variable is modeled according to Raudenbush and Bryk (2002). 


\section{Two level random-intercept fixed-slope logistic regression model}

LEVEL 1 MODEL

1) $\eta_{i j}=\beta_{0 j}+\sum_{k=1}^{n} \beta_{1 j} X_{k i j}+\xi_{i j}$

2) $p_{i j}=\frac{\exp \left(\eta_{i j}\right)}{1+\exp \left(\eta_{i j}\right)}$

$y_{i j}=1$ with probability $p_{i j}$

$y_{i j}=0$ with probability $1-p_{i j}$

3) $\log \left(\frac{p_{i j}}{1-p_{i j}}\right)=\beta_{0 j}+\sum_{k=1}^{n} \beta_{1 j} X_{k i j}+\xi_{i j}$

LEVEL 2 MODEL

4) $\beta_{0 j}=\gamma_{00}+\sum_{1} \gamma_{01} Z_{l j}+u_{0 j}$

5) $\beta_{1 j}=\gamma_{10}$

$$
u_{0 j} \sim N\left(0, \tau_{00}\right)
$$

FULL MODEL

6) $\log \left(\frac{p_{i j}}{1-p_{i j}}\right)=\gamma_{00}+\gamma_{10} X_{k i j}+\gamma_{01} Z_{l j}+u_{0 j} X_{k i j}+u_{0 j}+\xi_{i j}$

In the equations $x_{k i j}$ represents the student level covariates and $Z_{\mathrm{lj}}$ school level covariates. $\beta_{0 \mathrm{j}} . \beta_{1 \mathrm{j}}$ represent regression coefficients. $u_{0 \mathrm{j}} \sim N\left(0, \tau_{00}\right)$ are school specific random intercepts, uncorrelated across schools and uncorrelated with covariates. $\xi_{\mathrm{ij}}$ $\sim$ logistic are student-specific residuals, uncorrelated across students and schools, uncorrelated with $u_{0 \mathrm{j}}$ and with covariates. All multilevel estimations have been performed using HLM 6.25, which follows, for two-level models, the methodology suggested by Pfefferman et al (1998). 


\section{RESULTS}

The regression results are shown in Table 6. Annex A describes the variance reduction analysis. The interpretation of the odd-ratios depends on the specification of the variables and the sign of the coefficients. When the variable has a positive coefficient, every 0.1 over 1.0 represents a $10 \%$ increase in the probability that the student scores below level-2 in reading competency. On the contrary, if the coefficient is negative, every 0.1 under 1 represents a $10 \%$ decrease in the probability of obtaining a grade under level-2.

In two particular cases, variables were replaced due to the differences in the sample size and the information available in the database for the four PISA evaluations.

In the personal characteristics, the variable in the 2000 and 2003 regressions (COB) that distinguished students born in Spain from those born outside the country, was replaced by two variables, FGIM (first generation immigrant) and SGIM (second generation immigrant), for 2006 and 2009, with the purpose of illustrating the evolution of immigrant students in the school system in Spain in greater detail.

In school characteristics, as has been explained, the chosen threshold for the ratio of immigrant students/total students in the school was increased from $20 \%$ (IRATIO20) for 2000 and 2003 to 30\% (IRATIO30) for 2006 and 2009 in order to account for the progressive arrival of immigrant students in Spain and to capture significant effects.

Two mechanisms were used complementarily to check the correlations between independent variables with a correlation matrix and also to test the variance inflation factors $(\mathrm{VIFs})^{3}$. Level 1 and level 2 variables were inspected separately.

Table 6 shows the coefficients of the two-level logistic regressions, the signs of which reflect the relation between the explanatory variables (personal, household and school characteristics) and the dependent variable (probability of obtaining a score below level-2 in reading competency), and the odd-ratios or likelihood ratios and the robust standard errors.

3 We consider that if any of the VIF values is larger than 4 there are multicollinearity problems associated with the variable. 
Table 6: Multilevel logistic regressions fixed effects. Estimation for the probability of obtaining a score below level-2 in the reading competency PISA evaluations

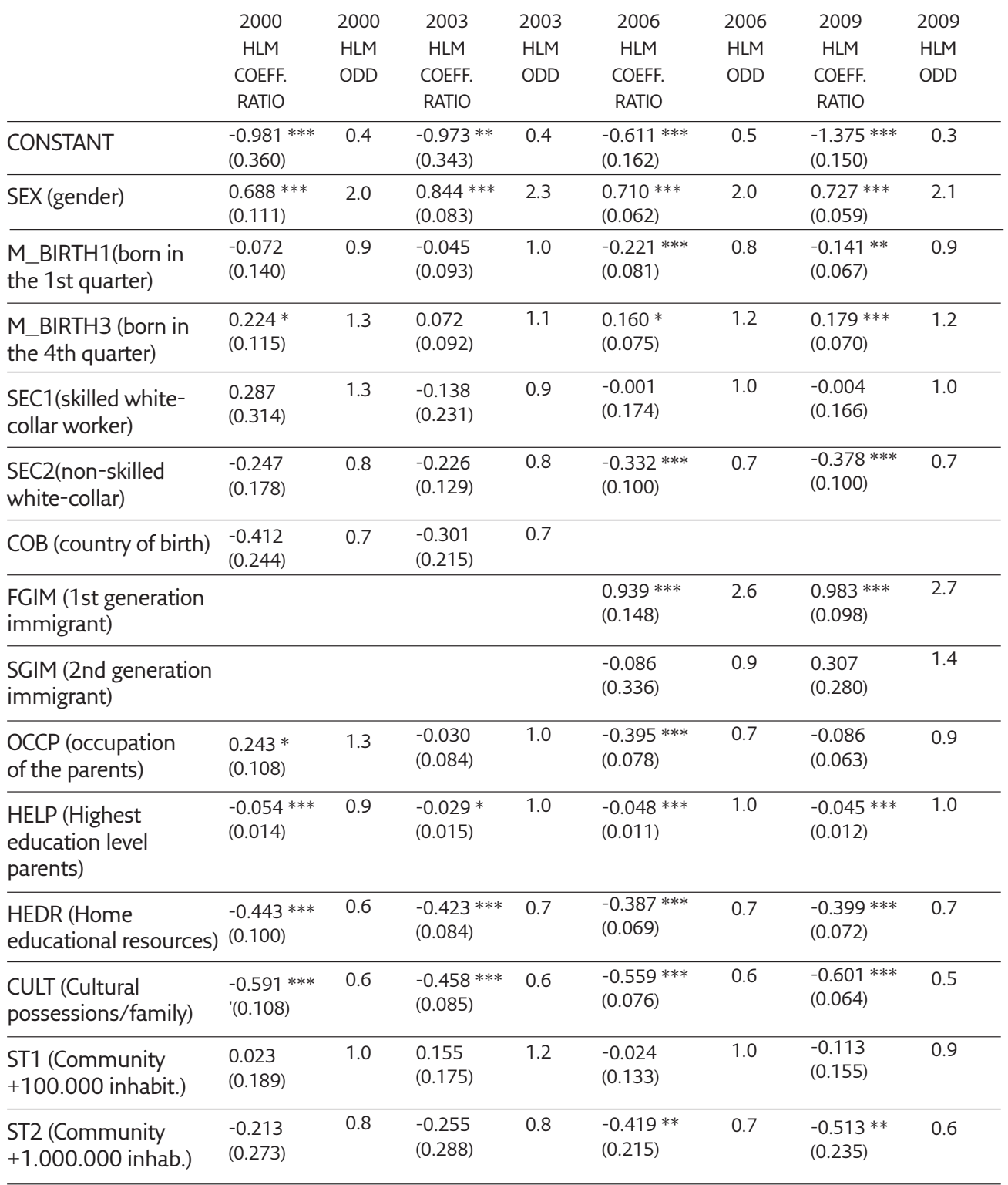


JUAN MANUEL GUIO JAIMES / ÁLVARO CHOI DE MENDIZÁBAL

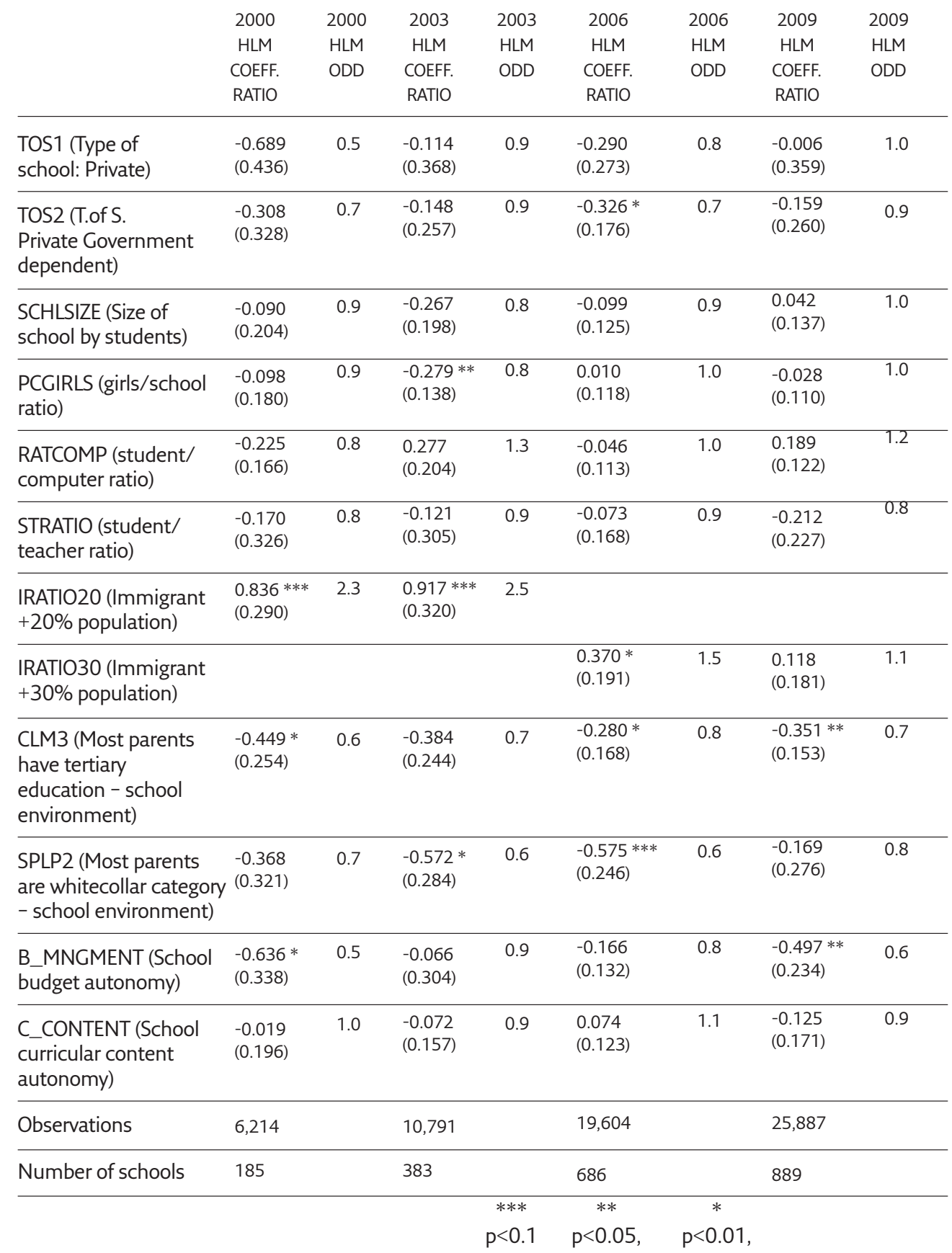


Note 1: $* * * \mathrm{p}<0.01, * * \mathrm{p}<0.05,{ }^{*} \mathrm{p}<0.1$, Standard errors in parentheses.

Note 2: The base category is constructed around these characteristics: Personal variables: Being female; being born between April and September; being born outside Spain. Household variables: Family whose parents belong to the blue-collar socio-professional category; parents not economically active; the household does not own educational resources and cultural possessions. School variables: Community has less than 100.000 inhabitants; state school; size of school by number of students, under or equal the average; percentage of girls in the school, under or equal the average; student-computer ratio, under or equal the average; student-teacher ratio, under or equal the average; immigrant students ratio, under or equal $20 \%$ of the population; academic environment of the schools consisting of parents who have attained primary and secondary level of education; the socio-professional environment of the schools, consisting of parents who belong to the blue-collar categories; school without autonomy in budget management and course content.

\section{Personal variables}

The first variable with considerable statistical significance in the regressions for the four years is the gender of the student. Being male increases one's chance of obtaining a result under level-2 in reading competency by over $100 \%$. This result is consistent in all the regressions: 100\% in 2000, 130\% in 2003, 100\% in 2006 and $110 \%$ in 2009.

This result implies that for every female student who obtains an unsatisfactory result in reading competency, there are at least two males in the same situation. The uniformity of the results over time seems to support the conclusions of Bertrand and Pan (2011) that showed that females have higher rates of success in the school system.

As suggested by Crawford et al. (2011), the month of birth seems to have a close relation to academic achievement and the cognitive skills of the students. This is not a surprising result as Sprietsma (2010), using PISA 2003 data, found a positive long term effect for relative age when entering primary school in 10 out of 16 countries analyzed.

The negative sign of the coefficient for the variable for students who were born from January to March, suggests that students born in the first quarter of the year are less likely to obtain a deficient result in the reading competency of the PISA evaluation. The same pattern is observed for the variable that describes the students born in the last quarter of the year, but with the opposite sign, indicating that students born from October to December are more prone to fail to obtain a result over level-2 in reading competency. These results also seem to support the findings by Robertson (2011), which show that students born in the first quarter of the year have a clear advantage in math and reading tests.

Regarding the origin of the students, a single variable that represents students who were born in Spain and whose parents are not from outside Spain was intro- 
duced for the 2000 and 2003 PISA evaluations. Not being an immigrant reduced the probability of being at risk of failure in reading competency by $30 \%$, compared with first and second generation immigrant students.

For 2006 and 2009, two variables were incorporated. The first variable corresponds to first generation immigrants and, as was anticipated, this variable was statistically significant for both years. The odd-ratios suggest that students born outside Spain and whose parents are first generation immigrants had a $160 \%$ higher risk of obtaining poor results in the reading test in 2006 and $170 \%$ in 2009, compared to their peers born in Spain.

The second variable corresponds to second generation immigrant students, those born in Spain but whose parents are both from outside Spain. The regression indicates that the variable is statistically non-significant for 2006 and 2009. These results suggest that second generation immigrant students do not perform differently to students born in Spain whose parents are also born within the country. Second generation immigrants obtain remarkably better results in the reading tests compared to first generation immigrant students.

\section{Household variables}

The variables describing family characteristics are divided into two categories. The first, attempts to characterize the family within a specific socio-economic and professional group, considering the educational achievement of the parents. The second group of variables represents the underlying relationship between achievement at school and the educational material and cultural resources of the household.

Socio-economic composition and educational level of the household The first variable in this category refers to parents with the highest socio-professional level: skilled white-collar workers. The results for this variable are statistically non-significant, so the odd-ratios results do not indicate a better performance by the students whose parents belong to this group in particular. However, students whose parents belong to the non-skilled white-collar socio-professional category seem to have a consistently lower probability of obtaining low results in the four years evaluated: 20\% less during 2000 and 2003, and 30\% less during 2006 and 2009 , compared to the base category of blue-collar workers. It is important to notice that these results are very significant for the 2006 and 2009 years.

The general tendency seems to be that when both parents work, there is a slight reduction in the possibility of obtaining a score under level-2 in reading com- 
petency, the 2000 regression being an exception, as its positive coefficient suggests the opposite relation. The effect seems to be consistent through time, but it is not possible to obtain a conclusive result.

Highest educational achievement by the parents has the effect of decreasing the risk of obtaining an unsatisfactory result in reading competency. Cordero, Crespo and Pedraja (2013) conclude that the majority of the literature using PISA data for Spain found this recurrent relation between the educational attainment of the parents and the academic results of the students. The continuous variable indicates that the higher the level of education of the parents the lower the probability of being at risk. It is important to mention that although statistically significant, the odd-ratios do not indicate an important reduction in the probability of obtaining a result below level-2 in the test, probably showing that the impact of parental education operates indirectly through other variables.

\section{Cultural and educational resources of the household}

The first variable in this category (HEDR) is an index provided by PISA that measures the possession of home educational resources. Results in Table 6 show that the possession of these resources is statistically very significant and decreased the probability of obtaining a low result in reading competence by $40 \%$ in 2000 , and by $30 \%$ during the 2003, 2006 and 2009 regressions.

The variable that incorporates the effect of cultural possessions within the family, CULT, gathers three elements together: whether the household owns classical literature, books of poetry or works of $\mathrm{art}^{4}$. The results of the regressions for this variable suggest that the presence of cultural elements in the home significantly reduces the risk of obtaining a result under level- 2 in reading competence by $40 \%$ for 2000, 2003 and 2006. However in 2009 cultural possessions seemingly had less of an effect on performance in comparison with that observed for the previous years.

4 Further explanation of the construction of HEDR and CULT can be found in OECD (2000; p.225); OECD (2003; p.283); OECD (2006; p. 316) and OECD (2009 I, p.112). 


\section{School variables}

School variables are divided into five categories: types of schools and their location, school inputs, school composition, environment of the schools and autonomy of the school.

\section{School characteristics}

The first two variables in this category are related to the size of the town/city where the school is located. They intend to capture whether the concentration of population has an effect on the results of the students that belong to schools in a certain area.

Schools located in municipalities with populations of over a million inhabitants present a remarkable result. The signs of the coefficients are stable and negative during the four years considered, but the effect of the variable, as the evolution of the coefficients suggests, appears to increase over time (Table 6), indicating that students from schools located in metropolitan zones have an increasingly lower probability of being at risk.

Within this category, a second group of variables considered are those that describe the schools by the type of ownership.

According to the results obtained by Calero and Waisgrais (2009), the ownership of the school appears to have a neutral effect on the probability of obtaining a deficient result in reading competency under level-2, with the sole exception of the students enrolled in private publicly-funded schools in 2006, where the risk of school failure was reduced by $30 \%$ compared to students attending state schools.

The last variable contemplated in this category, SCHLSIZE, describes the size of the school in terms of the number of students. As can be seen in Table 6, the proportion of students who perform poorly in reading competency appears to be large in schools where the number of students is under the average. However the lack of statistical significance underlines the neutral effect of the variable on the risk of school failure.

\section{School resources}

In this category two variables have been taken into consideration. The first measures the student-computer ratio. The second is the student-teacher ratio, identified by the STRATIO variable. Both variables are statistically non-significant in all the regressions. Overall, results in this category are consistent with those obtained by Calero, Choi and Waisgrais (2010). 


\section{School composition}

Three variables are considered in this category. The first describes the percentage of girls in the school population. The regression results indicate a positive impact on reducing the probability of school failure risk when the percentage of girls in the student population is over the average, but the estimates are only statistically significantly in 2003.

A ratio of immigrant students over $20 \%$ of the student population (IRATIO 20 ) is statistically significant for both the 2000 and 2003 regressions (Table 6). The positive sign of the regression indicates that students in schools with more than $20 \%$ of immigrant students had a higher risk (130\% and $150 \%$ respectively) of obtaining a result under level-2 in reading competency in 2000 and 2003.

In 2006 and 2009 the variable IRATIO20 was replaced by IRATIO30. This variable was introduced because exploratory regressions using the IRATIO20 variable showed that the results were not statistically significant for these two years. With the introduction of IRATIO30, the significance threshold of the variable was increased. This variable only considered schools in which immigrant students were over $30 \%$ of the total school population. The results show that this variable appears to be slightly significant only in 2006. These results are in line with most of the PISA-based literature for Spain, such as Cordero, Crespo and Pedraja (2013), which usually finds that the proportion of immigrant students in a school has negative effects on the academic results of the native students when it exceeds the $20 \%$ threshold.

\section{The school environment}

Schools with a large number of parents with ISCED 5 and 6 educational levels are compared to the rest of the schools. The results of the regressions indicate, as expected, that schools with a larger proportion of parents with tertiary education have a student population that appears to have a lower risk of obtaining a result below level-2 in reading competency compared to schools where the educational achievement of the parents is lower.

The other variable in this category, SPLP2, indicates schools in which a majority of families belong to the white-collar socio-professional category. The regression coefficients are negative and statistically significant in 2003 and 2006. The odd-ratios corroborate the idea that schools where there are more families whose parents are white-collar workers are characterized by students that appear to have a smaller probability of obtaining a poor result in the reading test evaluation. Students 
in this group of schools were 30\% less at risk in 2000, 40\% in 2003 and 2006 and $20 \%$ in 2009 . As can be observed, the tendency seems to be decreasing over time.

\section{School autonomy}

Two variables measure the degree of autonomy of the school in this category. The variable B_MNGMNT describes the level of school budgetary autonomy. The results of the regression are statistically significant in 2000 and 2009, at a level of $50 \%$ and $40 \%$ respectively, suggesting that a high degree of independence in the allocation of resources has an important effect in decreasing the risk of students obtaining low results in reading competency compared to schools with less autonomy.

The C_CONTENT variable denotes schools with a significant degree of autonomy in the selection of curriculum content. The lack of statistical significance implies that the variable has a neutral effect on the probability of obtaining a result under level-2 in reading competency. The regression outcomes for both school autonomy variables do not offer a conclusive result and further research is suggested for the future.

\section{Trends over the decade}

To compare the performance of students in reading competence over the 2000 decade, this final section describes the trends for a set of specific variables, tracking their evolution in PISA between 2000 and 2009. The calculation of changes in a variable between the 2000 and 2009 PISA tests will only be meaningful if its definition does not change in time. This is true for reading competency, the only competency for which the theoretical framework has remained unchanged throughout all the PISA tests (OECD, 2009a). We therefore calculate trend indicators following the three-step method suggested by the OECD (2009a) for two outcome variables: reading performance and the proportion of students below level-2.

The results in table 7 suggest that performance in reading competency by Spanish students has decreased during the 2000 decade. We have therefore split the analysis by gender, family origin and school ownership in order to provide possible explanations for this fact. Among all these subgroups, we only find a significant decrease in the performance of male students. A possible explanation for this result might be that, during the 2000 decade, non-skilled workers easily found wellpaid jobs in the Spanish labor market, mainly in the real estate and service sectors. In this context, a number of young -mainly male- students might not have found incentives for continuing with their studies. 
Table 7: Trends in PISA reading performance variables (2000 - 2009)

\begin{tabular}{lccccccc} 
& \multicolumn{2}{c}{2000} & \multicolumn{2}{c}{2009} & \multicolumn{2}{c}{$2009-2000$} \\
& $\begin{array}{c}\text { MEAN SCORE } \\
2000\end{array}$ & $\begin{array}{c}\text { STANDARD } \\
\text { ERROR }\end{array}$ & $\begin{array}{c}\text { MEAN SCORE } \\
2009\end{array}$ & $\begin{array}{c}\text { STANDARD } \\
\text { ERROR }\end{array}$ & $\begin{array}{c}\text { DIFERENCE } \\
2009-2000\end{array}$ & $\begin{array}{c}\text { STANDARD } \\
\text { ERROR }\end{array}$ & $\begin{array}{c}\text { STANDARDIZED } \\
\text { DIFFERENCE }\end{array}$ \\
\hline $\begin{array}{l}\text { Female } \\
\text { Male }\end{array}$ & 505 & 2,8 & 496 & 2,2 & -9 & 6,09 & $-1,48$ \\
Total & 481 & 3,4 & 467 & 2,2 & -14 & 6,38 & $-2,19$ \\
\hline $\begin{array}{l}\text { Publics } \\
\text { Schools }\end{array}$ & 493 & 2,7 & 481 & 2,0 & -12 & 5,97 & $-2,01$ \\
\hline $\begin{array}{l}\text { Private } \\
\text { Schools }\end{array}$ & 478 & 3,5 & 469 & 2,3 & -9 & 6,47 & $-1,39$ \\
\hline $\begin{array}{l}\text { Native } \\
\text { Students }\end{array}$ & 494 & 5,1 & 505 & 3,8 & -10 & 8,05 & $-1,24$ \\
\hline $\begin{array}{l}\text { 1st Generation } \\
\text { Immigrants }\end{array}$ & 450 & 15,9 & 428 & 3,9 & -22 & 17,10 & $-1,29$ \\
\hline $\begin{array}{l}\text { 2nd Generation } \\
\text { Immigrants }\end{array}$ & 460 & 17,8 & 464 & 8,4 & 4 & 20,29 & 0,20 \\
\hline
\end{tabular}

Source: OECD-PISA, 2000 and 2009 databases.

The results in table 8 , which presents the trend followed by the main outcome measured in this study, the proportion of students performing below level-2 in PISA, are consistent with this view. According to these results, the proportion of students who obtained a score below level-2 between 2000 and 2009 remained unchanged, suggesting a lack of significant advances in the reduction of school failure risk throughout the decade.

Table 8: Percentage of students with scores below level- 2 in reading competency

\begin{tabular}{lccccccc} 
& \multicolumn{2}{c}{2000} & \multicolumn{2}{c}{2009} & \multicolumn{2}{c}{$2009-2000$} \\
& $\begin{array}{l}\text { \% OF THE } \\
\text { POPULATION }\end{array}$ & $\begin{array}{c}\text { STANDARD } \\
\text { ERROR }\end{array}$ & $\begin{array}{c}\text { \% OF THE } \\
\text { POPULATION }\end{array}$ & $\begin{array}{c}\text { STANDARD } \\
\text { ERROR }\end{array}$ & $\begin{array}{c}\text { DIFERENCE } \\
2009-2000\end{array}$ & $\begin{array}{c}\text { STANDARD STANDARDIZED } \\
\text { ERROR } \\
\text { DIFFERENCE }\end{array}$ \\
\hline $\begin{array}{l}\text { Scores below } \\
\text { level-2 (female) }\end{array}$ & $11,5 \%$ & 1,1 & $14,6 \%$ & 0,9 & $3,1 \%$ & 1,42 & 0,02 \\
\hline $\begin{array}{l}\text { Scores below } \\
\text { level-2 (male) }\end{array}$ & $20,4 \%$ & 1,4 & $24,4 \%$ & 1,0 & $4,0 \%$ & 1,72 & 0,02 \\
\hline $\begin{array}{l}\text { Scores below } \\
\text { level-2 (total) }\end{array}$ & $16,3 \%$ & 1,1 & $19,6 \%$ & 0,9 & $3,3 \%$ & 1,42 & 0,02 \\
\hline
\end{tabular}

Source: OECD-PISA, 2000 and 2009 databases. 
Additionally, there are two PISA indexes, relevant to this study, that satisfy the necessary conditions for performing adequate time-trends estimations, as their definition remained identical between 2000 and 2009: HISEI (Highest International Socio Economic Index), and ESCS (Index of Economic, Social and Cultural Status $)^{5}$. The results in table 9 suggest that the HISEI index, constructed around a self-reported parental occupation indicator, has remained unchanged during the 2000 decade. The ESCS index is statistically different from zero between the two samples. The trend followed by this indicator -that measures the socio-economic background based on parent's education levels and occupational status and possessions at home- seems to imply an improvement in the socio-economic conditions of households in Spain during the decade. In other words, the reading performance of Spanish students decreased during the 2000 decade although the socioeconomic situation of their households improved. However, combining this finding with those presented in tables 8 and 9, it might also be the case that the improvement in the economic situation (reflected through the ESCS status) had a negative impact by reducing the student's incentives to study. Future studies should focus on this hypothesis. Nevertheless, the reduction in school failure rates observed in Spain since 2009 -the beginning of the economic crisis- seems to reinforce the credibility of this hypothesis and, in a sense, the expression "school failure" could be seen as unfair, as school characteristics might not be the main factors explaining the decrease in reading performance observed between 2000 and 2009.

Table 9: Trends in PISA variables other than performance: HISEI and ESCS (2000 - 2009)

\begin{tabular}{|c|c|c|c|c|c|c|c|}
\hline & \multicolumn{2}{|c|}{2000} & \multicolumn{2}{|c|}{2009} & \multicolumn{2}{|c|}{$2009-2000$} & \multirow[b]{2}{*}{$\begin{array}{l}\text { STANDARDIZED } \\
\text { DIFFERENCE }\end{array}$} \\
\hline & $\begin{array}{l}\text { HISEI } \\
2000\end{array}$ & $\begin{array}{l}\text { STANDARD } \\
\text { ERROR }\end{array}$ & $\begin{array}{l}\text { HISEI } \\
2009\end{array}$ & $\begin{array}{l}\text { STANDARD } \\
\text { ERROR }\end{array}$ & $\begin{array}{l}\text { DIFERENCE } \\
2009-2000\end{array}$ & $\begin{array}{l}\text { STANDARD } \\
\text { ERROR }\end{array}$ & \\
\hline $\begin{array}{l}\text { Highest } \\
\text { International } \\
\text { Socio Economic } \\
\text { Index (HISEI) }\end{array}$ & 44,99 & 0,6 & 44,40 & 0,5 & $-0,59$ & 0,78 & $-0,76$ \\
\hline $\begin{array}{l}\text { Index of Economic } \\
\text { Social and Cultural } \\
\text { Status (ESCS) } \\
\text { level-2 (male) }\end{array}$ & $-0,56$ & 0,05 & $-0,31$ & 0,03 & 0,25 & 0,06 & 4,29 \\
\hline
\end{tabular}

Source: OECD-PISA, 2000 and 2009 databases.

5 OECD (2009b) describes the items included in both indexes. 


\section{CONCLUSIONS}

The most interesting contribution of this paper to the previous literature on school failure risk is the possibility of observing the evolution over a whole decade of a group of factors that appear to have an important impact on the academic performance of students in Spain.

Among the personal variables the gender of the students has a strong effect on the probability of being at risk of school failure. Girls consistently perform better in reading competency than males. The ratio 2 to 1 appears unvarying throughout the decade, indicating that male students have twice the probability of school failure risk compared to female students. Although the real importance of gender mm may be overestimated d due to the specific selection of reading competence, school failure seems to be a mainly masculine issue in Spain. As has been explained, the relationship between school failure and the labor market deserves further research.

There is also a significant difference in the results for immigrant students compared to students born in Spain. This divergence is remarkably accentuated in the risk of school failure for first generation immigrants. The accumulation of a number of pre-conditions that seem to be characteristic of these particular students suggests that immigrant students begin from a situation of enormous disadvantage compared to national students. In this sense, policies that help to ease the process of integration of immigrants into Spanish society, and policies that increase the instruction time of immigrants in the schools, could have a positive impact on the academic performance of these students.

Household characteristics offer an important insight into the influence of the family environment on academic performance. Students with highly educated parents, belonging to the white-collar socio-professional category, along with the possession of cultural and educational resources at home, show that these things have a strong positive influence on the reduction of the risk of school failure. Therefore, further efforts should be made to reduce differences in family background and educational inputs at home. Focused grants and programs could be useful tools in achieving this objective.

Students in schools where over $20 \%$ of the total school population are immigrant students and in schools with a predominance of blue-collar families face a greater risk of school failure. In schools where parents with tertiary education are predominant, the risk to their students does not seem to decrease. Policies guaranteeing a more homogeneous distribution of immigrant students among schools, keeping ratios below $20 \%$, could have a powerful effect on the students' academic performance. The strong impact of school composition variables on academic out- 
come seems to support the need to reduce the segregation of students between public and private publicly-funded schools. If the educational system is meant to provide equality of opportunity to young citizens, strategies should be studied for reducing the over-concentration of low socio-economic level, immigrant students and blue-collar families in public schools.

Among the school variables the location of the school in a large city has a positive influence on the reduction of school failure risk, perhaps because of the availability of social, cultural and educational resources in more densely populated areas. After controlling for the socio-economic characteristics of the schools, the students in private and private publicly-funded educational institutions do not appear to have a lower risk of school failure than students from state schools.

The evolution of the determinants during the ten years covered by the study shows particularly stable behavior over time for personal characteristics which become, in general, more significant during the last half of the decade. Most of the household variables are also exceptionally stable during these ten years. Parental occupation deserves a special mention, appearing positively related to the risk of school failure in 2000 and then negatively related for the rest of the years. A possible hypothesis is that there is not necessarily a reduction in the risk of school failure for the economically active households, but perhaps there is an increase in the risk for those families facing problems in the labor market due to the economic crisis.

In contrast to the first-level variables, most of the school determinants are not significant during the decade. However, this fact does not imply the nonexistence of a relation between these variables and school failure risk. One reason behind the non-significance of school resources could be the specification of the model, focused on measuring the mean effects on the population sample. A possible alternative for future research is the analysis of heterogeneous effects by considering different subgroups.

It must be acknowledged that the cross-sectional analysis of the study of school failure risk is a limitation of this research. This paper, however constrained by these restrictions, has still provided relevant information on the cumulative processes that surround school failure. Indeed it has been shown that while the proportion of students at risk of school failure has remained relatively unchanged during the 2000-2009 period, overall performance has decreased. Although unable to establish a causal relationship, our study suggests the existence of factors external to the educational system, such as the labor market situation and the sectorial structure of Spain, which may be affecting these trends.

Future studies should simultaneously include the outcomes for the three competencies and, ideally, should draw on panel data. Also, more detailed studies going 
more deeply into the question of immigrant students and the difficulty of measuring peer effects would be relevant in subsequent works.

Fecha de recepción del original: 22 de enero de 2013

Fecha de aceptación de la versión definitiva: 25 de junio de 2013

\section{REFERENCES}

Aikens, N. and Barbarin, O. (2008). Socioeconomic differences in reading trajectories: The contribution of family, neighborhood, and school contexts. Fournal of Educational Psychology, 100(2), 235-251.

Berger, L. M., Hill J. and Waldfolgel J. (2005). Maternity Leave, Early Maternal Employment and Child Health and Development in the US. The Economic fournal, 115, 29-47.

Bertrand, M. and Pan, J. (2013). The Trouble with Boys: Social Influences and the Gender Gap in Disruptive Behavior. American Economic Fournal: Applied Economics, American Economic Association, 5(1), 32-64.

Choi, Á. and Calero, J. (2013). Determinantes del riesgo de fracaso escolar en España en PISA-2009 y propuestas de reforma. Revista de Educación, 362, 562-593.

Calero, J., Choi, Á. and Waisgrais, S. (2010). Determinantes del Riesgo de Fracaso Escolar en España: Una Aproximación a través de un Análisis Logístico Multinivel aplicado a PISA-2006. Revista de Educación, número extraordinario 2010, pp. 225-256.

Calero, J. and Escardibul, J. (2007). Evaluación de Servicios Educativos: el rendimiento en los centros públicos y privados medido en PISA-2003. Hacienda Pública Española, 183, 33-66.

Calero, J. and Waisgrais, S. (2009, February). Rendimientos Educativos de los alumnos inmigrantes: identificación de la incidencia de la condición de inmigrante y de los peer effects. XVI Encuentro de Economía Pública. Universidad de Granada, Granada.

Carrington, B., Tymss, P. and Merrell, C. (2008). Role Models, School Improvement and the Gender Gap. Do Men Bring out the Best in Boys and Women the Best in Girls? British Educational Research fournal, 34(3), 315-327.

Chingos, M. (2010). The Impact of a Universal Class-Size Reduction Policy: Evidence from Florida's Statewide Mandate. Economics of Education Review, 31, 543-562.

Cohen, P. (1987, April). A Critical Analysis and Reanalysis of the Multisection Validity meta-analysis. Annual meeting of the American Educational Research Association 1987, Washington. 
Coleman, J., Campbell, E., Hobson, C., McPartland, J., Mood, A., Weinfield, F. and York, R. (1966). Equality of Education Opportunity. Washington: U.S. Government Printing Office.

Cordero, J. M., Crespo, E. and Pedraja, F. (2013). Rendimiento educativo y determinantes según PISA: Una revisión de la literatura en España. Revista de Educación, 362, 273-297.

Cordero, J. M., Manchón, C. and García, M. Á. (2011). Los resultados educativos españoles en PISA 2009 y sus condicionantes. Investigaciones de Economía de la Educación, 6, 70-87.

Crawford, C., Dearden, L. and Greaves, E. (2011). Does when you are born matter? The impact of month of birth on children's cognitive and non-cognitive skills in England. Institute for Fiscal Studies. Retrieved November 8, 2012 from http://www.ifs.org.uk/bns/bn122.pdf

Entorf, H. and Minoiu, N. (2005). What a Difference Immigration Policy Makes: A Comparison of PISA Scores in Europe and Traditional Countries of Immigration. German Economic Review, 6 (3), 355-376.

Ferguson, R. and Ladd, H. (1996). How and Why Money Matters: An Anlysis of Alabama Schools. In R. Ferguson and H. Ladd, Holding Schools Accountable. Performance-Based Reform in Education (pp. 265-298). Washington D.C.: Brookings Institution Press.

Fernández, E., Mena, L. and Riviere, J. (2010). School Failure and Dropouts in Spain. Retrieved October 3, 2011 from http://obrasocial.lacaixa.es/deployedfiles/ obrasocial/Estaticos/pdf/Estudios_sociales/vol29_en.pdf

García, J. (2011). Nivel Socioeconómico, tipo de Escuela y Resultados Educativos en España: El Caso de TIMSS PIRLS 2011. (Vol. II, pp. 66-104) Retrieved January 21, 2012 from http://www.mecd.gob.es/dctm/inee/documentos-detrabajo/dtmontalvo.pdf? documentId=0901e72b814db8c1

Hanushek, E. A. (1997). Assessing the effects of School Resources on Student Performance: An Update. Educational Evaluation and Policy Analysis. 19, 141-64.

Hanushek, E. A. (2003). The Failure of Input-Based Schooling Policies. The Economic Fournal, 13, 64-98.

Haveman, R. and Wolfe B. (1995). The Determinants of Children's Attainments: A Review of Methods and Findings. Fournal of Economic Literature, American Economic Association, 33(4), pp. 1829-1878.

Holmes, C. T. (1989). Grade level retention effects: A meta-analysis of research studies. In L. A. Shepard and M. L. Smith (Eds.), Flunking grades: Research and policies on retention, (pp. 16-33). Philadelphia: The Falmer Press.

Instituto Vasco de Investigación y Evaluación Educativa (2009). Evaluación Diag- 
nostica 2009. Análisis de Factores y Variables. $2^{\circ}$ Educación Secundaria Obligatoria. Retrieved May 15, 2011 from http://isei-ivei.net/cast/pub/ED09_inf_variables/ED09_2ESO_variables.pdf

Jimerson, S. R. (2001). Meta-analysis of Grade Retention Research: Implications for Practice in the 21st Century. School Psychology Review, 30(3), 420-437.

Krueger, A. B. (2002). Economic Considerations and Class Size. The Economic Fournal, 113(485), 34-63.

Lavy, V. (2012). Do Differences in Schools' Instruction Time Explain International Achievement Gaps? Evidence from Developed and Developing countries. Retrieved August 17, 2011 from http://www.nberg.org/papers/w16227

Martin, A. (2009). Age Appropriateness and Motivation, Engagement, and Performance in High School: Effects of Age within Cohort, Grade Retention, and Delayed School Entry. Fournal of Educational Psychology, 101(1), 101-114. McCarthy, K. (1998). Adaptation of Immigrant Children to the United States: A Review of the literature. New Jersey: Center for Research on Child Wellbeing - Princeton University.

Ministerio de Educación (2009). Panorama de la educación. Indicadores de la OCDE 2009. Retrieved May 18, 2010 from http://www.mecd.gob.es/dctm/ievaluacion/internacional/indicadores-panorama-de-la-educacion-2009.pdf?documentId=0901e72b8046dc8d

Organisation for Economic Co-operation and Development (2000). PISA 2000: Technical Report PISA 2000. Retrieved August 10, 2011 from http://www. oecd.org/pisa/pisaproducts/33688233.pdf

Organisation for Economic Co-operation and Development (2003). PISA 2003: Technical Report PISA 2003. Retrieved August 10, 2011 from http://www.oecd. org/edu/school/programmeforinternationalstudentassessmentpisa/ 35188570.pdf

Organisation for Economic Co-operation and Development (2006). PISA 2006: Technical Report PISA 2006. Retrieved August 10, 2011 from http://www.oecd. org/pisa/pisaproducts/42025182.pdf

Organisation for Economic Co-operation and Development (2009a). PISA Data Analysis Manual. SPSS Second Edition. Retrieved August 10, 2011 from http://browse.oecdbookshop.org/oecd/pdfs/free/9809031e.pdf

Organisation for Economic Co-operation and Development (2010). Education at Glance 2010: OECD Indicators. Retrieved April 22, 2011 from http://www.oecd. org/education/skills-beyond-school/45926093.pdf

Organisation for Economic Co-operation and Development (2011). Education at 
Glance 2011: OECD Indicators. Retrieved July 7, 2012 from http://www.oecd. org/education/skills-beyond-school/48631582.pdf

Organisation for Economic Co-operation and Development (2010). PISA 2009 Results: Learning to Learn: Student Engagement, Strategies and Practices. Retrieved July 17, 2012 from http://www.oecd.org/pisa/pisaproducts/48852630.pdf

Pfeffermann, D., Skinner, C. J., Holmes D., Goldstein, H. and Rasbash, J. (1998). Weighting for Unequal Selection Probabilities in Multilevel Models. Fournal of the Royal Statistic Society, B, 60, 123-40.

Raudenbusch, S. and Bryk, A. (2002). Hierarchical Linear Models: Applications and Data Analysis Methods. Bethesda, Maryland: Sage Publications Inc.

Reynolds, A. and Temple, J. (1998). Extended Early Childhood Intervention and School Achievement: Age 13 findings from the Chicago Longitudinal Study. Child Development, 69(1), 231-246.

Robertson, E. (2011). The Effects of Quarter of Birth on Academic Outcomes at the Elementary School Level. Economics of Education Review, 30, 300-311.

Rubin, D.B. (1987). Multiple Imputation for non-response in surveys. New York: John Wiley \& Sons.

Schleicher, A. (2007). Can competencies assessed by PISA be considered the fundamental school knowledge 15-year-olds should possess? Fournal of Educational Change, 8(4), 349-357.

ANNEX A: VARIANCE REDUCTION ANALYSIS RESULTS

\begin{tabular}{ccccc}
2000 & VARIANCE COMPONENT & STANDARD DEVIATION & CHI-SQUARE & P-VALUE \\
\hline Null model & 0,845 & 0,919 & 871,38 & 0,000 \\
Full model & 0,326 & 0,569 & 413,72 & 0,000 \\
\hline 2003 & & & \\
\hline Null model & 0,855 & 0,925 & 1479,38 & 0,000 \\
Full model & 0,478 & 0,690 & 1005,15 & 0,000 \\
\hline 2006 & & & \\
\hline Null model & 0,838 & 0,916 & 2716,51 & 0,000 \\
Full model & 0,465 & 0,681 & 2055,64 & 0,000 \\
\hline 2009 & & & \\
\hline Null model & 1,000 & 1,000 & 4697,29 & 0,000 \\
Full model & 0,583 & 0,763 & 3246,37 & 0,000 \\
\hline
\end{tabular}

Note: The table reports the difference between the variance component for the unconditional model with random intercept (one-way ANOVA) and the full model. The table reports information about the outcome variability of within-group and between-group variance. The significant difference in the variance between groups in the four estimations justifies the use of hierarchical models. 